\title{
Techno-Economic Analysis for Small Scale Production of Rubber Seed Oil and Biodiesel in Palangkaraya, Indonesia
}

\author{
M. Y. Abduh, R. Manurung, and H. J. Heeres
}

\begin{abstract}
Estimation of production cost and sensitivity analysis for small scale production of rubber seed oil and biodiesel was studied. The production unit is projected to be built in the ex-Mega Rice Project area south of Palangkaraya, Indonesia which has a serious land degradation and deforestation problem. The valorization of rubber seed to produce bioproducts is seen as a contribution to revitalize the area. The production cost for rubber seed oil and rubber seed biodiesel in a small-scale ( 55 ton/y) was estimated to be $€ 0.42 / \mathrm{L}$ and $1.00 / \mathrm{L}$, respectively. This value is comparable with the price of diesel in remote areas in the ex-Mega Rice Project area close to Palangkaraya (up to $€ 1.25 / \mathrm{L}$ ). The effects of capital investment, production capacity, price of co-product credit, employees' salary and price of raw materials towards the production cost of rubber seed oil and biodiesel were investigated in the sensitivity analysis. The cost of capital investment has a relatively minor impact on the production cost of the rubber seed oil and biodiesel. The production capacity has a very strong influence in the production cost of rubber seed oil. The effect of other input variables is significant and all are showing about equal sensitivity.
\end{abstract}

Index Terms-Biodiesel, production cost, rubber seed oil, sensitivity analysis.

\section{INTRODUCTION}

The global market for biobased products is estimated to grow to $€ 200$ billion by 2020 [1]. The pace of this development may be enhanced by using a biorefinery concept which aims to optimise the use of resources and minimise waste production in order to maximise benefit and profitability for sustainable development [1]. In a biorefinery, a wide range of processes are coupled for the production of biobased products from various biomass feedstocks [2]. An attractive biorefinery scheme for rubber seeds from rubber trees (Hevea brasiliensis) is shown in Fig. 1. Rubber seeds are of particular interest as these are currently not valorised and regarded as waste. The rubber seed yield is reported to be in the range of 100-1200 kg/(ha.y) [3], [4]. From a biorefinery perspective, the identification of high added value outlets for the rubber seeds is highly relevant as it increases the profit for the rubber plantation to latex value chain [5].

The rubber seeds consist of a kernel (61 wt \%) surrounded by a hard shell (39 wt\%). The kernel contains $40-50 \mathrm{wt} \%$ of

Manuscript received March 4, 2016; revised May 14, 2016. This work was supported by the NOW/WOTRO.

M. Y. Abduh and R. Manurung are with the School of Life Sciences and Technology, Institut Teknologi Bandung, Jalan Ganesha 10 Bandung 40132, Indonesia (e-mail: yusuf@sith.itb.ac.id, manurung@sith.itb.ac.id).

H. J. Heeres is with the Department of Chemical Engineering, University of Groningen, Nijenborgh 4, 9747 AG, the Netherlands (e-mail: h.j.heeres@rug.nl). oil [6], [7] embedded in a protein rich matrix which can be isolated from the seeds by using for instance an expeller. By assuming the given composition and a rubber seed yield in the range of 100-1200 kg/(ha.y), the productivity of rubber seed oil (RSO) yield is estimated to be in the range $5-300 \mathrm{~kg} /$ (ha.y). The oil is a valuable source for the production of biodiesel (and by-product glycerol) and biopolymers [8], [9]. The protein rich press cake may find applications as a valuable source of protein [10], for instance to be used as cattle feed. In addition, the press cake may also be used for the production of biomaterials such as binderless boards [11], biogas and as the input for thermochemical processes like pyrolysis [12], [13].

The production of biodiesel from RSO can be carried out on different scale. For large-industrial scales (100 kton/y up to $250 \mathrm{kton} / \mathrm{y}$ ), the processing technology have higher efficiencies at the expense of expensive capitalisation and on site construction. The rubber seeds can be obtained in abundance from rubber tree plantations. However, the transport of raw material from its source and also the products to the end user is normally long distance and requires a high transportation cost.

Biodiesel can also be produced in small scale system $(<15$ kton/y) which requires less complicated and less expensive processing technologies and can be applied in rural areas. This may lower the capital cost and reduce the transportation cost of both the feedstock and product as well as improving the overall efficiency of the market delivery [14]. This study reported a preliminary techno-economic evaluation for small scale production of plant oil and biodiesel from rubber seeds in Palangkaraya, Indonesia. The production cost for RSO and biodiesel was estimated and sensitivity analysis was performed to evaluate the potential application of RSO as a feedstock for producing biodiesel.

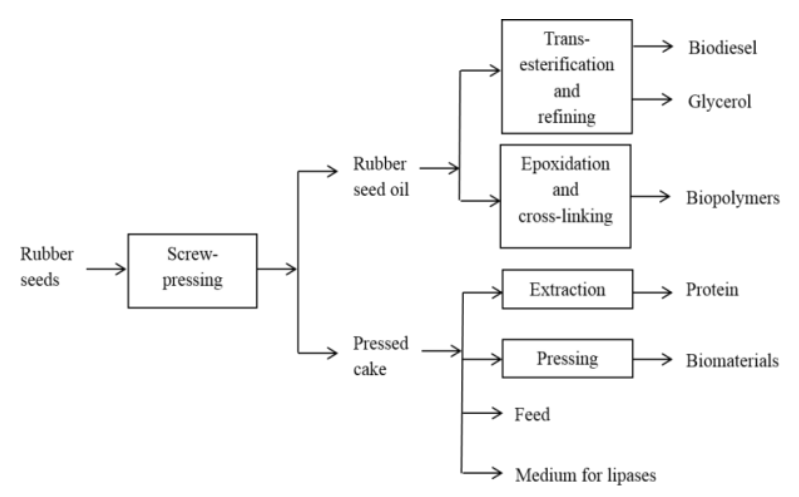

Fig. 1. Biorefinery scheme for rubber seed valorization.

\section{PROCESS DESCRIPTION AND MASS BALANCES}

The techno-economic evaluation reported in this paper is 
divided in two parts. The first part reports an evaluation for a small scale production unit of plant oil from rubber seeds using a screw expeller. The second part concerns the production of biodiesel on small scale from RSO using a continuous centrifugal contactor separator (CCCS) technology. CCCS is basically a device that integrates reaction and separation of liquid-liquid systems in a single device. Detailed description of the CCCS is described elsewhere [15]-[17]. Experimental and modelling studies on continuous synthesis and refining of biodiesel in a dedicated bench scale unit using CCCS technology has been reported by Abduh et al. [17]. From the study, it has been demonstrated that CCCS device is compact, robust and flexible in operation which allows continuous operation even at small scale.

The production unit is projected to be built in the ex-Mega Rice Project area south of Palangkaraya, the capital city of Central Kalimantan, Indonesia. During 1995-2006, this area of more than one million hectare of peat and lowland swamp was developed for large scale rice cultivation. However, due to improper peatland preparation, the land proved unsuitable for rice cultivation and this has led to serious land degradation and deforestation.

Currently about 110.000 ha is planted with rice. The average yields are low (1.5-2.5 tons/ha) due to poor land and water management. Small tree-farm based systems are mainly focused on rubber (33.500 ha) and coconut (24.500 ha) production. The valorisation of rubber seeds to produce biobased products is seen as a contribution to revitalize the area. Hence, a field study was carried out to collect rubber seeds in Palangkaraya. The RSO was then isolated from the seeds on site using a screw expeller and the oil was converted into biodiesel using a laboratory scale batch reactor. In the following, a preliminary techno-economic evaluation will be reported for the i) production of RSO from rubber seeds and ii) the conversion of RSO into biodiesel

\section{A. Small Scale Production of RSO from Rubber Seeds}

\section{1) Process description}

The production scale was set at an input of $60 \mathrm{~kg}$ wet rubber seed per hour, which is close to the maximum capacity of the available screw-press in the target area. With an estimated yield of $25 \mathrm{wt} \%$ of rubber seed oil on wet seeds, the estimated RSO production is $15 \mathrm{~kg} / \mathrm{h}$. When assuming $12 \mathrm{~h}$ per day of operation for 306 days a year, the annual RSO production of the unit is 55 ton. An overview of the RSO production unit is presented in Fig. 2. Rubber seeds are collected by the villagers in the target area during the harvesting season. The seeds typically have a moisture content of around $10 \mathrm{wt} \%$. Directly after harvesting, the seeds are dried in an oven operated at $60{ }^{\circ} \mathrm{C}$ to reduce the moisture content to $7 \mathrm{wt} \%$ to improve storage stability. The seeds are then stored in sealed plastic bags which are placed in a closed plastic container. The (whole) seeds are pressed using a screw-press. Initial tests showed that oil yields are improved when using whole seeds instead of dehulled seeds and as such a dehuller was not included in the process design. The resulting crude $\mathrm{RSO}$ is stored in an oil drum for several days to allow solids to settle. The clear RSO free of solids is collected and stored in closed plastic containers.

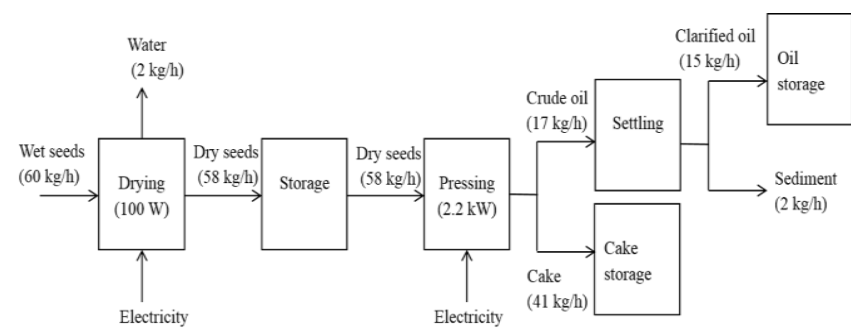

Fig. 2. Process flow diagram and mass balance for the production of RSO.

\section{2) Mass balances}

The mass balance of the process is given in Fig. 2. It assumes an input of $60 \mathrm{~kg} / \mathrm{h}$ of wet rubber seeds $(10 \mathrm{wt} \%$ water). After drying, $58 \mathrm{~kg} / \mathrm{h}$ of dried seeds ( $7 \mathrm{wt} \%$ water) are pressed using a screw-press. Assuming a crude RSO yield of $28 \mathrm{wt} \%$ on wet seeds, it is estimated that $17 \mathrm{~kg} / \mathrm{h}$ crude oil and $41 \mathrm{~kg} / \mathrm{h}$ of press cake can be obtained [18]. After settling of the crude oil, an estimated $2 \mathrm{~kg} / \mathrm{h}$ of sediment is formed whereas $15 \mathrm{~kg} / \mathrm{h}$ of clarified RSO is stored for further use.

\section{B. Small Scale Biodiesel Production Using CCCS Technology}

\section{1) Process description}

The production of RSO in the expeller unit is approximately $15 \mathrm{~kg} / \mathrm{h}$, see previous section for details. When assuming a $98 \mathrm{~mol} \%$ biodiesel yield from $\mathrm{RSO}$ in combination with a molecular weight of $0.890 \mathrm{~kg} / \mathrm{mol}$ and $0.298 \mathrm{~kg} / \mathrm{mol}$ for RSO and RSO methyl esters [8], respectively, the estimated production scale of the biodiesel unit is approximately $15 \mathrm{~kg} / \mathrm{h}$, which is equivalent to $55 \mathrm{ton} / \mathrm{y}$ biodiesel (12 h operation per day for 306 days per year). An overview of the biodiesel process is presented in Fig. 3. It involves storage vessels for feeds and products, a reactor/separator (CCCS), a crude biodiesel wash section, a biodiesel drying unit, a glycerol and methanol recovery unit.

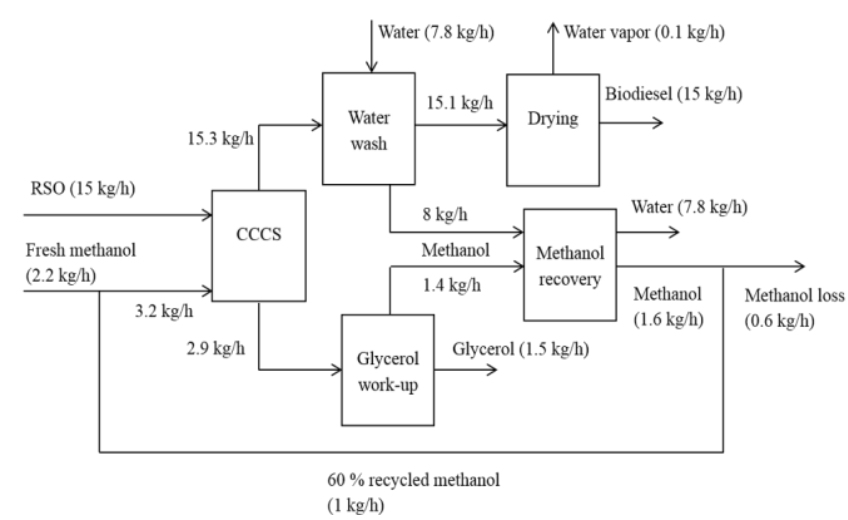

Fig. 3. Process flow diagram and mass balance for the production of RSO biodiesel.

A CCCS type CINC V05 with an estimated production capacity of 55 ton/y biodiesel is used as the reactor/separator. In the device, the RSO reacts with methanol in the presence of a catalyst $(\mathrm{KOH})$. It is assumed that potassium hydroxide has similar performance as sodium methoxide. It is assumed that the free fatty acid content in the RSO feed is below $1 \mathrm{wt} \%$ to exclude an initial acid catalysed esterification reaction. The methanol from the crude biodiesel and the crude glycerol are recovered using an alcohol recovery unit. 


\section{2) Mass balances}

The mass balance of the process is provided in Fig. 3 and is based on a $15 \mathrm{~kg} / \mathrm{h}$ RSO input. A 6:1 molar ratio of methanol to oil is used which is equivalent to an input of $3 \mathrm{~kg}$ methanol/h to the reactor. The required water for the biodiesel wash unit is set at $7.8 \mathrm{~kg} / \mathrm{h}$, which was found the best ratio as reported in our previous study [17]. After drying, $15.0 \mathrm{~kg} / \mathrm{h}$ biodiesel is produced. The water stream from the wash section, also containing dissolved methanol is fed to an alcohol recovery unit. An additional amount of methanol is recovered in the glycerol work-up. It is assumed that $60 \%$ of the excess methanol [19] can be recovered $(1 \mathrm{~kg} / \mathrm{h})$ and may be recycled to reduce the amount of fresh methanol used in the process $(2.2 \mathrm{~kg} / \mathrm{h})$. Besides biodiesel, $1.5 \mathrm{~kg} / \mathrm{h}$ of glycerol is also obtained in a glycerol-work up unit.

\section{COST Estimation AND SENSITIVITY ANALYSIS}

The total capital and production cost estimates for production of RSO and biodiesel are based on a cost estimation procedure by Garret [20] and Peters and Timmerhaus [21]. Overhead, research, financing as well as distribution and marketing cost are excluded from the calculation of the total production cost. Land acquisition is excluded from the capital costs, as the small scale unit is expected to require a limited amount of space.

\section{A. Small Scale Production of RSO from Rubber Seeds}

\section{1) Cost estimation}

The total equipment cost based on the process description and mass balance as shown in Fig. 2 are estimated at $€ 10.800$ (Table I). This cost includes storage facilities for oil cake residue as well as process equipment such screw press (60 $\mathrm{kg} / \mathrm{h}$ ), drying oven and weighing balance. The costs are based on online prices [22] and data available in the literature [23].

TABLE I: ESTIMATED TOTAL EQUIPMENT COST FOR A 55 TON/Y RSO
\begin{tabular}{lr}
\multicolumn{2}{c}{ PROCESSING UNIT IN PALANGKARAYA, INDONESIA } \\
\hline Item & Cost (€) \\
\hline Storage facilities & 2.000 \\
Seed Storage & 1.600 \\
Oil Storage & 2.000 \\
Cake Storage & 5.600 \\
Subtotal storage facilities & \\
Process equipment & 5.000 \\
Screw press, $60 \mathrm{~kg} / \mathrm{h}$ & 100 \\
Seed drying oven & 100 \\
Weighing balance, $100 \mathrm{~kg}$ & 5.200 \\
Subtotal process equipment & 10.800 \\
\hline Total equipment cost
\end{tabular}

The total capital investment (TCI) for the small-scale RSO production facility was estimated to be $€ 35$.620. This value is the sum of the fixed capital investment (FCI) and working capital investment (WCI), which were evaluated independently (Table II). An overview of the total production cost for a 55 ton/y RSO processing unit in Palangkaraya is given in Table III.
The cost of the rubber seed input was estimated at Rp1.500/kg. Assuming a currency exchange of $16.000 \mathrm{Rp} / €$, this equals to $€ 0.094 / \mathrm{kg}$. The annual electricity required for the process was estimated to be around $8800 \mathrm{kWh}$. Assuming an electricity cost of $€ 0.05 / \mathrm{kWh}[24]$, the annual cost for electricity is $€ 441$. The wages for the employees are based on the standard salary for employment in Indonesia $(€ 3 / \mathrm{h})$. Assuming 4 employees working a $6 \mathrm{~h}$ shift per day and that the unit is $12 \mathrm{~h} / \mathrm{d}$ in operation, the total employee costs is $€ 22.030$.

\begin{tabular}{lr}
\multicolumn{2}{c}{ PROCESSING UNIT IN PALANGKARAYA, INDONESIA } \\
\hline Item & Cost $(€)$ \\
\hline Direct Cost (DC) & 10.800 \\
Equipment cost (E) & 4.320 \\
Instrumentation and Control (0.4E) & 1.100 \\
Electrical Distribution System (0.1E) & 4.860 \\
Establishment of Equipment (0.45E) & 21.100 \\
Total DC & \\
Indirect Cost (IC) & 3.160 \\
Technical and Supervision (0.15DC) & 4.270 \\
Unexpected Expenses (0.15FCI) & 7.430 \\
Total IC & \\
Fixed Capital Investment (FCI) & 28.490 \\
FCI = DC + IC & \\
Working Capital Investment (WCI) & 7.120 \\
WCI = 0.2TCI & \\
Total Capital Investment (TCI) & 35.620 \\
TCI = FCI + WCI &
\end{tabular}

TABLE III: ESTIMATED TOTAL PRODUCTION COST FOR A 55 TON/Y RSO PROCESSING UNIT IN PALANGKARAYA, INDONESIA

\begin{tabular}{lr}
\hline Item & Cost $(\boldsymbol{€})$ \\
\hline Raw materials/year & 20.710 \\
Employees' salary/year & 22.030 \\
Electricity cost/year & 441 \\
Maintenance (0.01 FCI) & 285 \\
Operating supplies (0.1 salary) & 2.200 \\
Supervision (0.1 salary) & 2.200 \\
Administration cost (0.02 TPC) & 540 \\
Depreciation (0. 1 FCI) & 2.850 \\
Subtotal production cost & 51.240 \\
Co-product credit-press cake & 25.594 \\
Total production cost (TPC) & 25.676 \\
\hline
\end{tabular}

By assigning a market value of $€ 0.17 / \mathrm{kg}$ for the press cake [22], the total annual production cost is reduced to $€ 25.676$. Taking into account the total oil production of $55 \mathrm{ton} / \mathrm{y}$, the oil production cost is approximately $€ 0.47 / \mathrm{kg}$, which is $€ 0.42 / \mathrm{L}$ when assuming an RSO density of $0.91 \mathrm{~kg} / \mathrm{L} \mathrm{[6].} \mathrm{For}$ comparison, the diesel price at fuel stations in the city centre of Palangkaraya is approximately $€ 0.47 / \mathrm{L}$. However, the price of diesel outside the city is considerably higher and may be up to $€ 1.25 / \mathrm{L}$. As such, the RSO may be a competitive 
product for stationary electricity generation using a diesel engine.

\section{2) Sensitivity analysis}

A sensitivity analysis was performed to investigate the effect of input variables on the RSO production cost which includes price of press cake, cost or rubber seeds, employees' salary, production capacity and total capital investment. The sensitivity bounds for the input variables were set at 50 and $150 \%$ of the base case. The results of the sensitivity analysis are summarised in Fig. 4. Clearly, the capital investment cost has a relatively minor impact on the production costs of the RSO. Thus, optimisation of the design and reduction of the equipment costs should not be considered as a major research and development topic. The major variable is the amount of RSO produced in the unit. When the unit produces only 7.5 $\mathrm{kg} / \mathrm{h}$ instead of the projected $15 \mathrm{~kg} / \mathrm{h}$, the production costs of the RSO increases to $€ 0.93 / \mathrm{L}$. The effect of the other three input variables (price of press cake, salary costs and costs of the rubber seed) is significant and about equal.

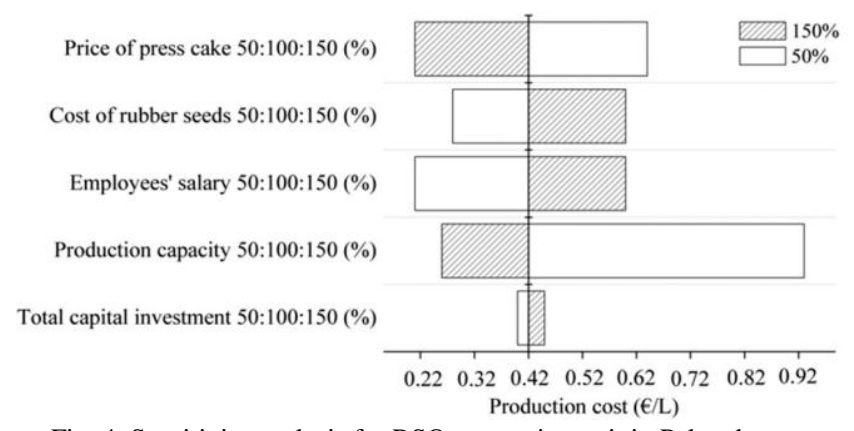

Fig. 4. Sensitivity analysis for RSO processing unit in Palangkaraya, Indonesia.

\section{B. Small Scale Biodiesel Production Using CCCS Technology}

\section{1) Cost estimation}

The total capital and production cost estimates are, like for RSO in the previous section, based on cost estimation procedure by Garrett [20] and Peters and Timmerhaus [21]. Overhead, research, financing as well as distribution and marketing are excluded from the calculation of the total production cost. Land acquisition is excluded from the capital costs, as the small scale unit is expected to require a limited amount of space.

The total equipment cost based on the process description and mass balance as shown in Fig. 3 are estimated at $€ 40.000$ (Table IV). The costs are based on online prices [22] and data available in the literature [20], [21]. The price of the CCCS was obtained from the supplier (CINC Industries). The equipment cost includes an RSO storage tank with a 30-day supply capacity.

The TCI for the small-scale RSO biodiesel production facility was estimated to be $€ 123.000$ (Table V). This value is the sum of the fixed capital investment (FCI) and working capital investment (WCI), which were evaluated independently. Almost one third of the capital investment is for purchase of equipment while the other two third are construction cost, indirect cost and working capital.

The cost of raw materials for the 55 ton/y biodiesel unit is provided in Table VI. The cost of RSO feedstock is the estimated price as provided in the previous section (€470/ton). The annual electricity consumption was not calculated in detail but taken as $10000 \mathrm{kWh}$, which is the reported electricity requirement for a small scale biodiesel production unit [23]. Assuming an electricity cost of $€ 0.05 / \mathrm{kWh}$, the annual electricity cost is $€ 500$.

TABLE IV: ESTIMATED TOTAL EQUIPMENT COST FOR A 55 TON/Y RSO BIODIESEL PROCESSING UNIT IN PALANGKARAYA, INDONESIA

\begin{tabular}{lr}
\hline Item & Cost (€) \\
\hline Storage facilities & \\
Oil storage tank & 1.600 \\
Biodiesel storage tank & 1.200 \\
Crude glycerol storage tank & 800 \\
Methanol storage tank & 800 \\
KOH storage tank & 400 \\
Biodiesel wash tank & 900 \\
Additional storage tank & 3.200 \\
Subtotal storage facilities & 8.900 \\
Process equipment & \\
Methanol/catalyst mixer & 250 \\
CCCS pre-heater & 250 \\
CCCS & 20.000 \\
Washing unit & 300 \\
Drying unit & 300 \\
Methanol recovery unit & 10.000 \\
Subtotal process equipment & 31.100 \\
Total equipment cost & 40.000 \\
\hline
\end{tabular}

TABLE V: ESTIMATED TOTAL CAPITAL COST FOR A 55 TON/Y RSO BIODIESEL PROCESSING UNIT IN PALANGKARAYA, INDONESIA

\begin{tabular}{lr}
\hline Item & Cost (€) \\
\hline Direct Cost (DC) & \\
Equipment cost (E) & 40.000 \\
Instrumentation and Control (0.4E) & 16.000 \\
Electrical Distribution System (0.1E) & 4.000 \\
Establishment of Equipment (0.45E) & 18.000 \\
Total DC & 78.000 \\
Indirect Cost (IC) & \\
Technical and Supervision (0.15DC) & 11.700 \\
Unexpected Expenses (0.15FCI) & 12.800 \\
Total IC & 24.500 \\
Fixed Capital Investment (FCI) & \\
FCI = DC + IC & 102.500 \\
Working Capital Investment (WCI) & \\
WCI = 0.2TCI & 20.500 \\
Total Capital Investment (TCI) & \\
TCI = FCI + WCI & 123.000 \\
\hline
\end{tabular}

The sub-total production cost for the biodiesel unit is estimated at $€ 64.162$ per year (Table VII). By assigning a market value of $€ 0.33 / \mathrm{kg}$ for the glycerol [24], the total annual production cost is reduced to $€ 62.344$. Combined with the annual production capacity (55 ton/y), the biodiesel production cost is approximately $€ 1.13 / \mathrm{kg}$, which is $€ 1.00 / \mathrm{L}$ when using a biodiesel density of $0.88 \mathrm{~kg} / \mathrm{L}$ [6]. 
TABLE VI: RAW MATERIAL COSTS FOR A 55 TON/Y RSO BIODIESEL PROCESSING UNIT

\begin{tabular}{lrr}
\hline Raw materials & Annual use (ton) & Annual cost (€) \\
\hline Rubber seed oil & 55 & 23.134 \\
Potassium & 0.6 & 44 \\
hydroxide & & \\
Methanol & 8.1 & 1.454 \\
Process water & 29 & 8 \\
Hydrochloric acid & 0.6 & 58 \\
& & 24.698 \\
\hline
\end{tabular}

TABLE VII: ESTIMATED TOTAL PRODUCTION COST FOR A 55 TON/Y RSO BIODIESEL PROCESSING UNIT IN PALANGKARAYA, INDONESIA

\begin{tabular}{lr}
\hline Item & Cost $(\boldsymbol{\epsilon})$ \\
\hline Raw materials/year & 24.698 \\
Employees' salary/year & 22.030 \\
Electricity cost/year & 500 \\
Maintenance $(0.01 \mathrm{FCI})$ & 1.025 \\
Operating supplies $(0.1$ salary) & 2.200 \\
Supervision (0.1 salary) & 2.200 \\
Administration cost $(0.02 \mathrm{TPC})$ & 1.250 \\
Depreciation (0. 1 FCI) & 10.250 \\
Subtotal production cost & 64.162 \\
Co-product credit-glycerol & 1.820 \\
Total production cost (TPC) & 62.344 \\
\hline
\end{tabular}

\section{2) Sensitivity analysis}

A sensitivity analysis was performed to investigate the effect of input variables on the RSO biodiesel production costs which includes price of glycerol, cost or RSO, employees' salary, production capacity and total capital investment. The sensitivity bounds for the input variable were set at 50 and $150 \%$ of the base case. The results of sensitivity analysis are shown in Fig. 5. Production capacity has the largest effect on the production cost. A reduction in the plant capacity to $50 \%$ leads to an increase in the biodiesel price to $€ 1.99 / \mathrm{L}$. An increment in the plant capacity to $150 \%$ leads to a decrease in the biodiesel price to $€ 0.66 / \mathrm{L}$. Other important input variables are the salaries and the cost of the RSO oil. As with the RSO unit, the total capital investment has a rather limited effect on the biodiesel production costs. The selling price of the co-product glycerol has the least effect on the production cost and as such of less importance.

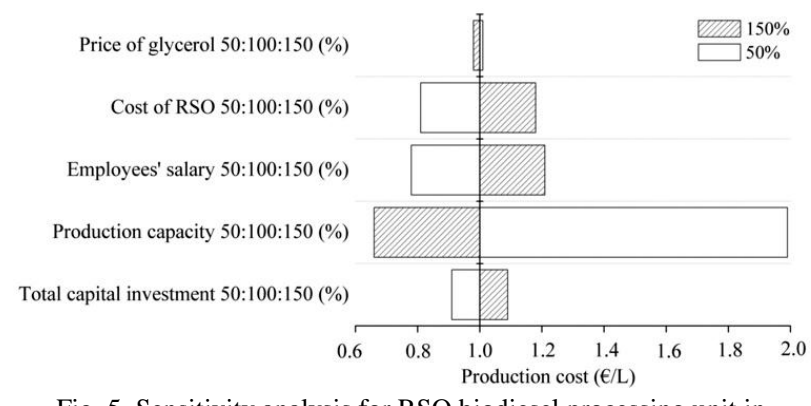

Fig. 5. Sensitivity analysis for RSO biodiesel processing unit in Palangkaraya, Indonesia.

\section{CONCLUSIONS AND OUTLOOK}

The production cost for RSO in a small-scale rubber seed expeller unit ( 55 ton $\mathrm{RSO} / \mathrm{y}$ ) in Palangkaraya were estimated to be $€ 0.42 / \mathrm{L}$. The capital investment cost has a relatively minor impact on the production cost of the RSO. Thus, optimisation of the design and reduction of the equipment costs should not be considered as a major research and development topic. The major variable is the amount of RSO produced in the unit. When the unit produces only $7.5 \mathrm{~kg} / \mathrm{h}$ instead of the projected $15 \mathrm{~kg} \mathrm{RSO} / \mathrm{h}$, the production cost of the RSO increase to $€ 0.93 / \mathrm{L}$. The effect of the other three input variables (market price of press cake, salary costs and costs of the rubber seed) is significant and all are showing an about equal sensitivity. For comparison, the diesel price at fuel stations in the city centre of Palangkaraya is approximately $€ 0.47 / \mathrm{L}$. However, the price of diesel outside the city is considerably higher and may be up to $€ 1.25 / \mathrm{L}$. As such, the RSO may be a competitive product for stationary electricity generation using a diesel engine both in Palangkaraya as well as the rural areas in the ex-Mega rice project.

In addition, the total production cost for biodiesel at small scale (55 ton/y) from RSO using CCCS technology was also evaluated and found to be $€ 1.00 / \mathrm{L}$. This value is comparable with the price of diesel in remote areas in the ex-mega rice project area close to Palangkaraya (up to $€ 1.25 / \mathrm{L}$ ). The CCCS technology is also particularly suitable for mobile biodiesel unit application due to its compactness, robustness and flexibility in operation.

\section{ACKNOWLEDGMENT}

Authors thank NWO/WOTRO for a research grant in the framework of the Agriculture beyond Food Program.

\section{REFERENCES}

[1] The World Economic Forum, The Future of Industrial Biorefineries. [Online]. Available: http://www3.weforum.org/docs

[2] F. Cherubini, "The biorefinery concept: using biomass instead of oil for x producing energy and chemicals," Energy Conversion and Management, vol. 51, pp. 1412-1421, 2010.

[3] D. Stosic and J. Kaykay, "Rubber seeds as animal feed in Liberia," Wld Animal Review, vol. 39, pp. 29-39, 1981.

[4] B. Abdullah and J. Salimon, "Physicochemical characteristics of Malaysian rubber (Hevea Brasiliensis) seed oil," European Journal of Scientific Research, vol. 31, pp. 437-445, 2009.

[5] O. Ikwuagwu, I. Ononogbu, and O. Njoku, "Production of biodiesel using rubber Hevea brasiliensis (Kunth Muell.) seed oil," Industrial Crops and Products, vol. 12, pp. 57-62, 2000.

[6] A. S. Ramadhas, S. Jayaraj, and C. Muraleedharan, "Biodiesel production from high FFA rubber seed oil," Fuel, vol. 84, pp. 335-340, 2005.

[7] O. Njoku, I. Ononogbu, and A. Owusu, "An investigation on oil of rubber seed (Hevea brasiliensis)," Journal of Rubber Research. Institute of Sri Lanka, vol. 78, pp. 52-59, 1996.

[8] M. Y. Abduh, R. Manurung, and H. J. Heeres, "The influence of storage time on relevant product properties of rubber seed, rubber seed oil and rubber seed oil ethyl esters," Sustainable Chemical Process.

[9] M. Y. Abduh, M. Iqbal, R. Manurung, F. Pichioni, and H. J. Heeres, "Synthesis and properties of cross-linked polymer from epoxidized rubber seed oil using triethylenetetramine," Journal of Applied Polymer Science, vol. 132, issue 40, 2015.

[10] R. Widyarani, E. Ratnaningsih, J. P. M. Sanders, and M. E. Bruins, "Biorefinery methods for separation of protein and oil fractions from rubber seed kernel," Industrial Crops and Products, vol. 62, pp. 323-332, 2014.

[11] H. Hidayat, E. Keijsers, U. Prijanto, J. van Dam, and H. Heeres, "Preparation and properties of binderless boards from Jatropha curcas L. seed cake," Industrial Crops and Products, vol. 52, pp. 245-254, 2014.

[12] C. M. Vaz, L. A. de Graaf, and W. J. Mulder, "Adhesives, coatings, and bioplastics from protein sources," Biopolymers Online, vol. 8, 2005.

[13] A. M. J. Kootstra, H. H. Beeftink, and J. P. Sanders, Industrial Crops and Products, vol. 34, pp. 972-978, 2011. 
[14] S. Bernesson, D. Nilson, and P. Hansson, "A limited LCA comparing large-and small-scale production of rape methyl ester (RME) under Sweedish conditions," Biomass Bioenergy, vol. 26, pp. 545-559, 2004.

[15] M. Y. Abduh, W. Van Ulden, V. Kalpoe, H. H. Van de Bovenkamp, R. Manurung, and H. J. Heeres, "Biodiesel synthesis from Jatropha curcas L. oil and ethanol in a continuous centrifugal contactor separator," European Journal of Lipid Science and Technology, vol. 115, pp. 123-131, 2013.

[16] M. Y. Abduh, W. Van Ulden, H. H. Van de Bovenkamp, T. Buntara, F. Pichioni, R. Manurung, and H. J. Heeres, "Synthesis and refining of sunflower biodiesel in a cascade of continuous centrifugal contactor separators," European Journal of Lipid Science and Technology, vol. 117, pp. 242-254, 2014.

[17] M. Y. Abduh, A. F. Martinez, A. Kloekhorst, R. Manurung, and H. J. Heeres, "Experimental and modelling studies on continuous synthesis and refining of biodiesel in a dedicated bench scale unit using centrifugal contactor separator technology," European Journal of Lipid Science and Technology, vol. 117, 2015.

[18] M. Y. Abduh, C. B. Rasrendra, E. Subroto, R. Manurung, and H. J. Heeres, "Experimental evaluation and modelling of solvent assisted hydraulic pressing of dehulled rubber seeds," Industrial Crops and Porducts, unpublished.

[19] M. Noordam and R. V. Withers, "Producing biodiesel from canola oil in the Inland Northwest: An economic feasibility study," University of Idaho College of Agriculture, Idaho, 1996.

[20] D. E. Garett, Chemical Engineering Economics, New York: Van Nostrand Reinhold, 1989.

[21] M. S. Peters and K. D. Timmerhaus, Plant Design and Economics for Chemical Engineers, New York: McGraw-Hill, Inc., 1991.

[22] Alibaba. [Online]. Available: http://www.alibaba.com

[23] S. S. Nevase, S. Gadge, A. Dubey, and B. Kadu, "Economics of biodiesel production from Jatropha oil," Journal of Agricultural Technology, vol. 8, pp. 657-662, 2012.

[24] R. M. Swanson, J. A. Satrio, R. C. Brown, A. Platon, and D. D. Hsu, "Techno-economic analysis of biofuels production based on gasification," National Renewable Energy Laboratory, NREL/TP-6A20-46587, 2010.

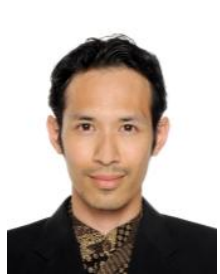

M. Yusuf Abduh graduated in 2015 from the Department of Chemical Engineering, University of Groningen, the Netherlands with a PhD thesis on the development of biobased products from rubber, jatropha and sunflower oil.

$\mathrm{He}$ is a faculty member at the School of Life Sciences and Technology, Institut Teknologi Bandung, Indonesia since 2010. Before that, he was trained as a hydraulic modelling engineer at Danwater Malaysia.
His research interest is primarily on the valorization of renewable source to produce biobased products using a biorefinery concept.

Dr. Abduh is a member of the Asia-Pacific Chemical, Biological \& Environmental Engineering Society and Crossing Biological Membranes Network.

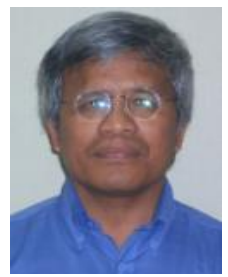

Robert Manurung graduated in 1993 from the Department of Chemical Engineering, University of Groningen, the Netherlands.

Afterwards, he performed a post-doctoral research at the Massachusetts Institute of Technology Energy Laboratory, USA. He was appointed as an associate professor at the Department of Chemical Engineering, Institut Teknologi Bandung since 2001. He was the director of University Library, Institut Teknologi Bandung from 2001 to 2003. He was also the director of Biotechnology Research Center, Institut Teknologi Bandung from 2005 to 2007. He is currently an associate professor at the School of Life Sciences and Technology, Institut Teknologi Bandung, Indonesia since 2010. He is the (co-) author of more than 100 full-length publications in scientific journals, conference and seminar papers in the field of process development related to biobased products: bioenergy and biochemical.

Dr. Manurung was a member of The Combustion Institute, American Chemical Society and American Institute of Chemical Engineers from 1994 until 2004.

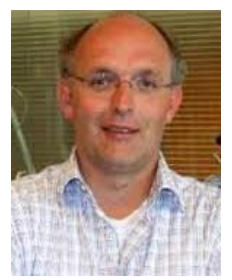

H. J. Heeres graduated in 1990, from the University of Groningen, with a $\mathrm{PhD}$ thesis on the development of novel homogeneous lanthanide catalysts for the conversion of unsaturated hydrocarbons.

Afterwards, he performed a post-doctoral research at the University of Oxford, in the group of J. M. Brown on asymmetric catalysis. From 1991 to 1999 , he was employed at Shell Research, in Amsterdam and Pernis, and worked on a range of applied catalysis topics. He joined the Chemical Engineering Department of the University of Groningen, in 1999, as an assistant professor. Four years later, he was appointed as full professor in green chemical reaction engineering. His research interests primarily on acid-based and metal-based catalytic biomass conversions, with an emphasis on biofuels (pyrolysis oil upgrading), platform chemicals and performance materials from biomass. He is the (co-)author of 215 publications and 7 patents in the field of (applied) catalysis and chemical reaction engineering

Prof. Heeres is actively involved in national and international consortia such as the European Union $6^{\text {th }}$ Framework and many others. 